\title{
İstanbul Sözleşmesi İçin Çocuk Vakfindan Açıklama ve Öneri Notu
}

-11 Ağustos 2020-

\section{Açıklamanın Gerekçesi}

İstanbul Sözleşmesi ile ilgili açıklama ve öneri notu, Sözleşme'nin onaylanmasından bu yana ilgili mevzuatın düzenlenmesi, uygulama sonuçları, çocuk, kadın ve erkeklerin yaşadıkları mağduriyetlerin giderilmesi konusunda Çocuk Vakfı Danışma Kurulu Üyelerinin değerlendirme ve önerileri, Sözleşme'yi imzalayan ülkelerdeki tartışmalar, henüz Sözleşme'yi onaylamayan ülkelerin yaklaşımları ve İstanbul Sözleşmesi Türkiye İzleme Grubu (GREVIO) Raporu (2018) dikkate alınarak hazırlanmıştır.

Açıklama ve öneri notu okunduğunda anlaşılacağı gibi Çocuk Vakfının yaklaşımı, günlük politikanın dışında kalarak kamuoyu önünde Sözleşme'yi savunan ve Sözleşme'den çekilinmesini öneren tarafların yanında değil, sorunun öznesi olan kadına karşı ve aile içi şiddet karşısında ve kadına saygı temelinde KADIN'dan yana taraf olarak somut önerilerde bulunan bir tutumu ortaya koymaya yöneliktir. Çocuk Vakfının varoluş gerekçesi hiçbir ayrım gözetmeksizin çocuktan ve onu doğrudan ve dolaylı ilgilendiren her gerçeklikten yana tereddütsüz taraf olmaktır. Bu bağlamda tarih boyunca kadına yönelik bütün eşitsizliklerin çocuk sorununa da dönüştüğünü görmekteyiz. Üçüncü maddede problemli bir şekilde tanımlanmasına karşın, İstanbul Sözleşmesi'nin kız çocuklarına yönelik şiddeti Sözleşme kapsamında kabul etmesi bizce tesadüf değil yerinde bir kabuldür...

Cinsiyet, bireylerin siyasi, kültürel, ideolojik, ırki ve kültürel tercihi değil, doğuştan kazanılmış ve hiçbir gücün ve yasanın değiştiremeyeceği evrensel bir haktır. Unutulmamalıdır ki kadın önce insan'dır. Çok sık vurgu yapılan, pozitif ayrımcılık söylemi kadına karşı bir koruma kalkanı oluşturuyor gözükse bile baştan insan onuruna aykırıdır.

$-R A P O R-$ 
Bugün Türkiye'nin asıl beka meselesi aile ve çocuk meselesidir. Kadın ise bu sorunların biriktiği öbektir. Bu öbekten bakıldığı zaman sorunların hem ana kaynağı hem de yayılım alanı açıkça görülecektir.

\section{İstanbul Sözleşmesi Sarmalı}

İstanbul Sözleşmesi, Türkiye'nin Avrupa Konseyi Dönem Başkanlığı ve Avrupa Konseyi Parlamentosu Meclis Başkanlığı döneminde inisiyatif alması ile hazırlanmasına öncülük ettiği ve ilk olarak Türkiye tarafından imzalanan (11 Mayıs 2011), 47 ülkenin imzaladığı bir sözleşmedir. Sözleşme, TBMM Genel Kurulu'nda oy birliğiyle onaylandığı tarihten (24 Kasım 2011) yürürlüğe girdiği (1 Ağustos 2014) tarihine kadar toplumda tartışılmadığı gibi, TBMM aşamasında Sözleşme'nin bugün tartışılmakta olan boyutu üzerinde ülke yaklaşımı ortaya konulamamış ve Sözleşme çekincesiz kabul edilmiştir.

İstanbul Sözleşmesi İzleme Grubu GREVİO ilk raporunda (2018), Türkiye'nin kadına yönelik şiddetin etkin şekilde önlenmesi yönündeki çalışmalarından “endişeli” olduğunu açıklamıştı. Sözleşme’nin uygulanmasıyla ortaya çıkan sonuçlar karşısında, 6284 sayılı kanunun geliştirilerek yeniden düzenlenmesi yanında Aile Hukuku, Çocuk Hukuku, Ceza Hukuku çerçevesinde ve bütün bileşenlerini kapsayacak şekilde kadına karşı ve aile içi şiddetin önlenmesi için düzenleme yapılması gerekirken Sözleşme tartışmaya açılmıştır. Kadına yönelik şiddetin siyasi görüş bağlamında tartışılması neticesinde herhangi bir çözüm üretilemediği gibi, söz konusu şiddetin önlenmesi yönünde adımlar da atılamamış oldu. Türkiye'de düşünce hareketlerinin insan hakları temelinde kadın sorunlarını çözmeye yönelik bakış açıları geliştiremediği sonucuna da ulaşılmıştır.

Dünyada cinsiyetsizlik ve farklı cinsel yönelimlerin yaygınlaştırılmasına yönelik akımların olduğu ve bu akımların medya ve iletişim gücünü kullanarak toplumları dönüştürücü emellerinin olduğu bilinmektedir. Bu konuda gösterilen duyarlılık anlaşılmak ve paylaşılmakla birlikte tartışma zemini olarak İstanbul Sözleşmesi'nin sembolleştirilmesi sorunu odağından uzaklaştırmaktadır. Aile kurumunu güçlendirici, aile sorunlarını çözmeye yönelik politikalar geliştirilmediği sürece hiçbir enstrümanın, propagandanın yardımı olmaksızın toplumsal erimenin artarak devam edeceği unutulmamalıdır. Ülke ölçekli bir aile politikası olmadıkça ne aile,

Çocuk ve Medeniyet 2021/1 ne kadın, ne de çocuk korunamaz. Çok uzun yıllardan beri ihmal edilen aile kurumu, bütün bireyleri ile birlikte zayıflatıcı unsurlara açık hâle gelmiştir. Asıl endişelenilmesi gereken budur. 
Bu durum ise, İstanbul Sözleşmesi’nin eksiksiz, hatasız bir Sözleşme olduğu anlamına gelmemektedir. İstanbul Sözleşmesi'ne yüklenen aşırı anlamlar, sözleşme ortadan kalkınca her şeyin düzeleceği veya sözleşmeye taraf olmakla kadına yönelik şiddetin ortadan kalkacağı gibi bir yanılgıya yol açmaktadır. Sözleşme'ye dair şüphe ve endişelerin aşılması zor değildir. Aşağıda öneri 1'de belirtilen beyanda bulunma usulü ile tereddütler giderilebilir. Ancak meselenin esası; Sözleşme'den önce de var olan ve artarak devam eden kadına yönelik ve aile içi şiddetin temel kaynağı olan aile kurumunun zayıflamasıdır. Kadın, çocuk, erkek; kime yönelirse yönelsin aile içi şiddetin temel sebeplerinden biri aile kurumunun zayıflamasıdır. İstanbul Sözleşmesi'ne yöneltilmesi gereken temel eleştiri, şiddeti önleyici değil şiddet ortaya çıktıktan, adli bir vakaya dönüştükten diğer bir ifade ile kadın mağdur olduktan sonra onu korumaya alan anlayışa ağırlık vermesidir. Sözleşme, şiddet ortaya çıktıktan sonra devreye giren mekanizmaları esas alan, şiddetin ortaya çıkmasını önleyici hizmet ve mekanizmaları ise yeterince barındırmayan bir görünüme sahiptir. Özellikle aile içi şiddetin hiçbir surette ortaya çıkmaması aile kurumunun sağlıklı işleyişi için gerekli sosyal hizmet ve desteklerin verilmesi ile mümkün olabilecekken Sözleşme aile boyutunu ihmal etmekte, önleyici tedbirler konusunda herhangi bir vizyon ortaya koymamaktadır 6284 sayılı Ailenin Korunması ve Kadına Karşı Şiddetin Önlenmesine Dair Kanun da Sözleşme ile benzer bir içeriğe sahiptir. Kanunun adında "ailenin korunması" ifadesi geçmekte ancak kanun metninde ailenin korunmasına dair en ufak bir hükme yer verilmemektedir. Korumanın öncelikli koşulunun, koruma gerektiren olumsuzlukların ortaya çıkmasını engellemek olduğu gerçeği, bu düzenlemelerde ihmal edilmiştir. 6284 sayılı Kanunun, Sözleşme'den kopuk ve genel hükümler içermesi ve uygulanmasında ortaya çıkan adaletsiz sonuçlar bu kanunun yeniden düzenlenmesini zorunlu duruma getirmiştir.

İstanbul Sözleşmesi'nin bir başka eksikliği, şiddeti doğuran sosyal ve ekonomik farklı sebepleri kapsamı içerisine almayarak şiddetin dayanağını toplumsal cinsiyet ile sınırlandırmasıdır. Bu tesadüfi değildir ve Sözleşme bir tercihte bulunmaktadır. Bu sınırlandırma, kadına karşı şiddet ile mücadele kapsam ve içeriğini zayıflatma pahasına yapılmış politik bir tercihtir. Uluslararası sözleşmeler daha çok ülkenin imzalaması ve etkin bir uygulamanın ön şartı olan içeriğin benimsenmesi bakımından mümkün olduğunca geniş kapsam ve esneklikte hazırlanan belgeler olmalarına rağmen İstanbul Sözleşmesi bu sınırlandırıcı yaklaşımı tercih etmiştir.

Çocuk ve Medeniyet 2021/1 Cinsiyetsizlik ve farklı cinsel yönelimlerin yaygınlaştırılması için elverişli bir hukuki zemin ve meşruiyet sağlayacağına yönelik endişeleri giderecek hükümlerin bulunmaması da sözleşmenin eksiklilerindendir. 
İstanbul Sözleşmesi'nde tartışılan kavramlar, Türkiye'nin onayladığı çok sayıda Çocuk/Genç/Kadın/Aile/İnsan Hakları belgesinde yer almış kavramlardır. Modern uygarlığın insan hakları bağlamında seküler dil ve söylemi karşısında çözüm üretemeyen toplumlar, çözüme yönelik dil ve söylem geliştirmedikçe bu çaresizlik sarmalı devam edecektir.

Sözleşme, bu sorunlarına rağmen kadınlara yönelik ve aile içi şiddetle mücadele bakımından önemli bir referans olma özelliğini korumaktadır. Bu nedenle; Türkiye, Sözleşme'den çekilmek yerine Sözleşme'nin eksiklerinin giderilmesi için Avrupa Konseyi nezdinde üye ülkeleri harekete geçirerek inisiyatif almalıdır. Sözleşme'nin 10. yılı olan 2022 yılında Avrupa Konseyi'ne sunulacak ve 10 yıllık uygulamanın analizini içerecek kapsamlı ortak çalışmalar ile Sözleşme'nin daha etkin hâle getirilmesi, eksikliklerinin giderilmesi, aile kurumunun güçlendirilmesi ve şiddetin ortaya çıkmasını önleyici hizmetlerin sözleşmenin esaslı unsuru hâline geleceği değişiklik önerileri ortaya konulmalı ve Türkiye bu konuda öncü bir rol üstlenmelidir. Bunu yaparken, ülkemizde etkin mücadelenin sağlanabilmesi için öncelikle ülke ölçekli aile politikası geliştirilmeli ve iç mevzuattaki eksiklikler de ivedilikle giderilmelidir.

İstanbul Sözleşmesi özelinde Sözleşme'nin imzalanması ve onaylanması aşamalarında diğer belgelerde izlenen yol izlenebilir, Sözleşme kavramlarına ve hükümlerine yaklaşımı ve çekinceler ortaya konulabilirdi. Türkiye, Sözleşme'ye taraf ülke olarak uygulama sürecini ve toplumdaki tartışmaları dikkate alarak Sözleşme'nin 72. maddesine dayanarak Sözleşme'yi nasıl anladığını ve yaklaşımını Avrupa Konseyi’ne bildirebilir. Türkiye, bir adım daha ileri giderek Sözleşme’yi imzalayan ülkelerdeki tartışmaları ve Sözleşme'yi henüz onaylamamış 13 ülkenin gerekçelerini de dikkate alarak Sözleşme'nin yenilenmesine de öncülük edebilir.

İstanbul Sözleşmesi, 6 yıllık uygulanma aşamasında kadına yönelik ve aile içi şiddetin önlenmesinde yeterli olmadığı gibi bu dönemde şiddet daha da artış göstermiştir. Türkiye, bu aşamada İstanbul Sözleşmesi'nden çekilmek yerine, hem kadına yönelik hem de aile içi şiddetle etkin mücadele edeceğini açıklamalıdır. Çünkü kadına yönelik ve aile içi şiddetin nedeni İstanbul Sözleşmesi olmadığı gibi, bu sözleşme kadına karşı şiddetin önlenmesi için yol haritalarından yalnızca biridir. Kaldı ki; Türkiye bu tür sorunlarını kendi hukuku ve kavramları ile çözebilecek potansiyele ve birikime sahiptir. Dileriz Türkiye bu potansiyel ve birikimi ile koronavirüs salgını sonrası ortaya çıkan dünyadaki insan açığı karşısında bölgesel değil, küresel çözüm önerileri geliştiren, kadına yönelik ve aile içi şiddeti asgari düzeye indiren örnek bir ülke durumuna gelir... 


\section{Çocuk Vakfindan Beş Öneri}

1. Türkiye'nin, taraf olduğu İstanbul Sözleşmesi'nin başta çekince konulamayacak maddeler olmak üzere, tartışılan bütün kavramlar ve söylemler ile Sözleşme'nin uygulanmasından kaynaklanan sorunların ve eksikliklerinin nasıl giderileceği noktasında bütün tarafların görüşlerini yansıtacak bir rapor hazırlayarak Sözleşme'nin güncellenmesine öncülük etmesi; Sözleşme'de tereddüt oluşturan hükümlerin Türkiye tarafından ne şekilde anlaşıldığı ve uygulanacağı hususunda Avrupa Konseyi'ne bildirimde bulunulması; bu çabaların sonuçsuz kalması hâlinde Sözleşme'nin askıya alınması veya çekilme kararının gündeme alınması.

2. Koronavirüs salgını sonrası ortaya çıkan yeni sosyolojiyi dikkate alarak kadına yönelik ve aile içi şiddetin boyutlarını kapsayan politika ve strateji geliştirilmesi, İstanbul Sözleşmesi ve ilgili sözleşmelerin hayata geçirilmesi amacıyla temel yaklaşımı mağdur kadının korunması değil, kadının mağdur edilmesinin önlenmesi olan Aile İçi Şiddet ve Kadına Yönelik Şiddetin Önlenmesi Stratejisi ve Acil Eylem Planı hazırlanması.

3. İstanbul Sözleşmesi'nin uygulanmasına yönelik hazırlanan 6284 sayılı Ailenin Korunması ve Kadına Karşı Şiddetin Önlenmesi Kanunu'nun Medeni Hukuk, Aile Hukuku, Çocuk Hukuku, Ceza Hukuku çerçevesinde ve 5395 sayılı Çocuk Koruma Kanunu, 4721 sayılı Medeni Kanun, 5237 sayılı Türk Ceza Kanunu'nda ailenin korunması, çocuğa karşı şiddet, aile içi şiddet, kadına karşı şiddet ve toplumsal şiddeti önleyici, koruyucu ve caydırıcı gücün arttırılmasını kapsayacak yasal düzenlenmelerin gerçekleştirilmesine öncelik verilmesi.

4. Toplumsal bütün özne ve paydaşların katılımı ile Aile, Çocuk, Genç, Kadın, Yaşı Politikalarının güncellenmesi ve geliştirilmesi.

5. Aile ve Çocuk Bakanlığı'nın kurulması: Aile ve Sosyal Politikalar Bakanlığı ile Çalışma ve Sosyal Güvenlik Bakanlığı'nın birleştirilmesi aile, çocuk, genç, kadın, yaşlı ve engellilerin sorunlarını çözümsüzlüğe ittiği gibi Bakanlık, aile, çocuk, kadın, genç, yaşlı ve engelli sorunlarının çok uzağına düşmüştür. Hiç zaman kaybetmeden toplumsal etkinliği ve işlevi ailenin bütün öznelerinin sorunlarını çözmeyi amaçlayan, işlevi yardım dağıtmakla sınırlı olmayan, icracı yönü etkin bir Aile ve Çocuk Bakanlığı kurulması. 